\title{
THE SOCIAL BRANCH: A NEW MECHANISM FOR ECONOMIC JUSTICE
}

\author{
Rareș Vlad BUNEA \\ Financial Services Institute Fellow, Life Management Institute Fellow, Toronto, Canada \\ bunea@protonmail.com \\ Lucian T. BUTARU, PhD \\ Faculty of European Studies, Babeș-Bolyai University Cluj-Napoca, Romania \\ lucian.butaru@ubbcluj.ro
}

\begin{abstract}
The neoliberal policies activated since the 1970s have created unprecedented levels of wealth and income inequality, stagnating social mobility, aggravating effects that compound the climate crisis, and especially little prospects for an improvement of the general welfare of all citizens, not just the ruling wealthy. Many theoretical mechanisms have been proposed to fix the ailments of capitalism, Universal Basic Income (UBI) being amongst the most transformative and cutting-edge. These policy proposals all suffer a great shortcoming: they must be political. Leftwing and rightwing governments take turns at running UBI pilots then cutting them immediately after winning elections (Forget, 2018). The challenge to a solid long-term solution that brings economic justice for the many, not just the few, is to overcome the politics. This means deploying broad-spectrum and reasonable (re)distribution models that satisfy both the laissez-faire desires of the libertarian enthusiasts and the sentiments of solidarity of left-leaning activists. A transformative (re)distribution paradigm must become apolitical and must transcend the traditional separations of power in the state. This paper outlines the high-level attributes of this new mechanism: what it would look like, why it is so necessary, and how can be realized given the tremendous pressures imposed by the climate crisis.
\end{abstract}

Keywords: Universal Basic Income, International Institution, Wealth Socialization.

\section{Introduction}

Present social insurance systems that have evolved through historical negotiation between the left and the right are full of cracks. On one hand, according to the right, they are an impediment against growth and must be flexibilized. On the other hand, according to the left, they do not cover 
well enough the needs of society. It may as well be possible that both sides are correct and wrong at the same time since the problems are generated by the paternalist language in which the current economic system has been conceived: based on needy social groups and on a work ethic in which equitable redistribution is focused on excluding the lazy free rider. Such a system based on citizens who need social protection cannot cover all possible scenarios so governments should arbitrarily draw lines and then employ a lot of energy, imagination and resources determining on what side of the line a person falls (Widerquist, 2013). Scandals immediately erupt: this individual has taken advantage of the system, that individual was left unjustly on the outside. Development traps also pop up for folks who do not want to lose their social benefits and for the nation's competitivity which is hurt by the global race to the bottom on social issues. These problems and inconsistencies accumulate with the alternation at power between the left, the right, and the in-betweens.

Therefore, there is a need for a radical revision of the ways we understand, conceptualize and solve the social problem. Breaking the ideological divide begins with how one navigates the semantics of (re)distribution. What is wealth? What is value? Are there built-in rules of nature that allow some to navigate on rafts and others on speedboats? From the left ideological spectrum to the right, the contention about who deserves this wealth and in what proportion to their effort has become so divisive, so pernicious, it has led to dangerous short-termism in thinking, terrible frustration of dispossessed workers, rise of racism, nationalism and extremism.

Moreover, there is a need for visionary ideas that can plant the seeds for "utopias for realists" (Bregman 2016), "save capitalism from itself” (Collier 2018, Reich 2015, Yang 2018), find alternatives to capitalism (Hahnel \& Wright, 2016), reconsider what truly matters in life (Hägglund, 2019) and finally "play for team human" (Rushkoff, 2019). We have made significant theoretical progress, while numerous grassroots movements sprung in unlikely corners to utter words of foundational change, from the Occupy Movement to the Extinction Rebellion. Perhaps there is a way to navigate the thick ideological web and travel on a plain of economic justice.

Do nations fail because of this never-ending left vs. right bickering? Acemoğlu and Robinson (2012) make a compelling case that prosperity rises on the shoulders of political institutions that must be inclusive and centralized. It is the political struggle against privilege that makes prosperity possible, not geography, not culture, not race, not disease. Inequality is a feral beast that comes at a hefty price (Stiglitz, 2012), and allows rentier capitalists to take over the status-quo narrative (Standing, 2017). To counter them, regulation is paramount, reaffirming the separation of powers 
is essential (Stiglitz, 2019). There is a big need for collective action, and for legitimate institutions that inspire public trust.

The world sat on a GDP of $\$ 85$ trillion in 2018 (World Bank), while in 2016 the top 10\% earners took in $37 \%$ of national income in Europe, $41 \%$ in China, $46 \%$ in Russia, $47 \%$ in USCanada, 54\% in Sub-Saharan Africa, 55\% in Brazil and India, 61\% in the Middle East (World Inequality Report 2018). While the top earners have taken the lion's share of total growth since 1980, net public capital (public assets minus public debts) has declined sharply from $60-70 \%$ to $20-30 \%$ in Russia and China, and even became negative in the US and the UK. Personal wealth inequality has also increased. In the US the top $1 \%$ wealth share rose from $22 \%$ in 1980 to $39 \%$ in 2014. Abundant data show how wealth and income inequalities are at historical heights.

As if these problems were not enough, we face the deleterious effects of "bullshit jobs" (Graeber, 2018), automation, and artificial intelligence (Bostrom, 2014). Amazon already delivers parcels by drones, Tesla is making driverless trucks, retail at large is pushed into extinction. Bill Gates talks about taxing the robots in the context where the American economy, among others, is under way to automate away 43\% of jobs (Frey \& Osborne, 2017: 254). How we look at work and its value translated into products is more outdated by the day. Automation will accelerate this trend by taking over most tasks that are easily measured and financialized. Already we can see a significant decoupling between income and labor, while chance and luck produce more wealth than before (Butaru, 2017: 93-94).

Wise policies can make a difference if they tackle the substance of what matters. We ought to preserve employability while the wave of technological innovation continues to grow implacably, increase the minimum wage, deploy progressive taxation, create a national wealth fund (Atkinson, 2015). Even ideas that may look eccentric at first glace, such as radical markets ${ }^{3}$ (Weyl \& Posner, 2018) have the potential to become mainstream.

\footnotetext{
3 Take for example Weyl \& Posner's idea for quadratic voting (QV). QV “would allow people to express the relative strength of their preferences in the democratic process. No longer would 51 people who support a proposal, but barely care about the issue, outvote 49 incredibly passionate opponents, predictably making society worse in the process. Instead everyone would be given 'voice credits' which they could spread across elections as they chose. QV follows a square root rule: 1 voice credit gets you 1 vote, 4 voice credits gets you 2 votes, 9 voice credits gives you 3 votes, and so on. It's not immediately apparent, but this method is on average the ideal way of allowing people to more and more impose their desires on the rest of society, but at an ever-escalating cost. To economists it's an idea that's obvious, though only in retrospect, and is already being taken up by business. Weyl points to studies showing that people are more likely to vote strongly not only about issues they care more about, but issues they know more about. He expects that allowing people to specialise and indicate when they know what they're talking about will create a democracy that does more to aggregate careful judgement, rather than just passionate ignorance." From: https://80000hours.org/podcast/episodes/glen-weyl-radically-reforming-capitalism-and-democracy.
} 
While a detailed discussion over the semantics of (re)distribution is essential, we skip it here and fast-forward to the key points of this proposal: it is essential to redefine value; redefine economic indices; libertarianize the redistribution of wealth; depoliticize the bulk of fiscal policies; accelerate the transition of growth-based economies into Green New Deal-like systems. This transformation requires institutional change which can be facilitated by the social branch.

\section{What Is the Social Branch?}

The social branch is an institution whose mission will be the administration of the (re)distribution of socialized national and international wealth. Its foundation will be a Universal Basic Income (UBI). The social branch is a trans-political institution, short of becoming the fourth power in the government. Its staff and administrators, while being elected or appointed through deliberation and consensus, will have no political affiliation. The social branch will not issue fiscal policy ${ }^{4}$ and will administer by charter amendable through public forums. Some executive fiscal policies will be converted into algorithmic rules. The social branch will make direct cash payments through an operational arm, the National Account of Wealth (NAW), and will operate under the assumption that no means testing is required to participate in foundational wealth distribution. The aim of the social branch is to shift fiscal power from the executive and legislative and transform it into a catalog of algorithmic rules of (re)distribution based on dynamic input from real-life economic data ${ }^{5}$. The catalogue will be updated regularly by popular ballots and forums, while the executive and legislative will not have veto-power. In this sense, the social branch may be a broadening of the separation of powers and will not fall at the mercy of electoral cycles.

While the foundation of the social branch is an UBI, its body will be comprised of social shares. The new mechanism saves the concepts of private property, entrepreneurship, capitalbased market economy, and recognizes the need to rebalance nature with material output, effort with reward, labor income with capital income. The social shares are capital-like participation shares in all private ventures that operate in the nation. Unlike regular stock, the social shares will

\footnotetext{
${ }^{4}$ Worth mentioning the Commitment to Equity Handbook - Estimating the Impact of Fiscal Policy on Inequality and Poverty edited by Nora Lusting (2018) of CEQ Institute, Tulane University. The main message is that one must look at both the tax and spending sides simultaneously. Taxes can be regressive, but when combined with transfers make the system more equalizing, while redistribution is quite heterogeneous and fiscal systems are not always poverty reducing.

5 A report from the Complex Systems Institute justifies wealth redistribution with mathematics. https://necsi.edu/preliminary-steps-toward-auniversal-economic-dynamics-for-monetary-and-fiscal-policy.
} 
have a non-voting, mandatory distributary function that will mimic the global capital taxation proposed by Piketty (2013). Social shares will be owned by the citizenry through the mediation of the social branch.

The institution can be scaled to a supranational level under the umbrella of ECOSOC (United Nations Economic and Social Council). A primary source of financing can be the value added tax (VAT) collected at national level. The secondary source can be a portion of social shares issued by multinational corporations that generate global economies of scale. Several advantages immediately ensue.

First, this method of reframing sovereignty seems to be the easiest that can be integrated with the current political arena. The European technocratic experiment shows that political roadblocks that appeared during attempts to redefine the exercises of sovereignty can be overcome more easily at supranational level. While at national level, political games and talks about redefining sovereignty fall under the heavy hammer of tradition and status quo vocabulary, especially when the subject is the transfer of a significant portion of fiscal policy outside the national boundaries.

Second, expanding the mechanism to a supranational level would address a problem of equity. Through an international redistribution (UBI-style) of a chunk of national VAT, the mechanism would impose a non-negligible sanction over those who, for various reasons, consume most of the global production and subsequently deliver the highest carbon footprint.

Third, maneuvering carefully the rate of VAT collected and through commensurate currency policy, this global social branch could serve as an instrument of economic macrostability in partnership with institutions like IMF and World Bank. This global redistribution mechanism would subsidize the global production while enhancing economic justice and safeguarding the competitive market space.

Many authors have proposed valid calculations for UBI funding (Smith-Carrier, Green, Forget, Standing, etc.). We hold these facts to be self-evident, that there is enough money to fund UBI projects in all advanced nations. However, this is not enough, yet it lays at the foundation of the social branch. The swaths of capital laying both in economies of scale (see Amazon, Big Tech, etc.) and in the underground fiscal paradises (see Panama Papers) can be tapped into carefully with pragmatic solutions (Collier, 2018) which will allow all citizens to participate in this enormous wealth of nations. 
Income taxation will be reformed to create separate streams of funding that will feed partially into the standard national revenue agencies, and partially into the NAW, more so into the latter ${ }^{6}$. At the same time the burden of social spending will be drastically lifted from the shoulders of the government, hence the libertarian framing. Certain social protection programs that require demographic customization and means testing will remain outside the purview of the social branch.

Fine-tuning the social branch, following a simple philosophy of collect-and-pay, can allow the mechanism to radiate transformational change into society at large. Capital creation, market forces, labor rights, effort-to-pay ratios, monopolies, unfair extraction of values from the commons, the destruction of the environment by private capital interest, will find their way into the algorithms behind the amounts NAW will collect and then pay monthly to all citizens.

\section{Why the Social Branch?}

Any serious attempt at proposing foundational new economic mechanisms must build its legitimacy on strong, universally accepted moral precepts. Such as free market liberalism is grounded on the principle to each according to their effort, which has been hijacked by neoliberalism and morphed into to each according to their gluttonous audacity. While social democracy, where often Marx is present in "homeopathic quantities" (Bunea, 2019), is grounded on the principle to each according to their needs, which has morphed into to each according to minimizing the total general dissatisfaction. Half-baked policies on the left have pushed the population into corners of apathy when it comes to social democracy, leaving the job of revival to populist grassroots movements who now have the difficult task to take on the establishment on the battlefield of moral principles. The grand battle of our times is moral.

Formulating the UBI question in moral terms allows us to deliver the necessary consensus for creating such an institution since this consensus is not beyond ideological divisions, but beside (Butaru, 2015). Consensus can be found in the meditations on fixing the shortcomings of industrial civilization, formulated by Thomas Paine, Joseph Charlier, Allen Davenport etc. (Cunliffe \& Erreygers, 2004). This consensus, from the times when the old left had not divided yet into liberals

\footnotetext{
6 Personal income tax can be separated into two streams, both progressive. One stream would flow into government coffers, the other stream (steeper) into the social branch. This does not mean, however, a higher tax burden for lower and medium-income people.
} 
and socialists, can be rebuilt easily in the present, since on moral territory "real-libertarians can side with the old critics of alienation" (Van Parijs, 1998: 34). By reducing both poverty and excessive affluence (Frankfurt, 2015) we can reduce inequality, as a side effect. By taking a pragmatic position (Collier, 2018) we can replace state paternalism with social maternalism, where the state would not empower itself excessively but remains active in both the economic and social spheres.

Moral philosophers and legal scholars have debated for centuries the source of human rights. More recently, even President Franklin D. Roosevelt proposed a second bill of economic rights in 1944 because the historical bill of rights, comprised of the first ten amendments to the United States Constitution, had "proved inadequate to assure us equality in the pursuit of happiness". Indeed, the moral landscape of human experience can have a bottom line, whether it is the pursuit of happiness, or the pursuit of wellbeing, or the pursuit of prosperity. Regardless of how they are encoded into human rights charters, all these pursuits are inextricably anchored in what nature can offer: the lands, the waters, the air, the resources. This is the defining nucleus of human existence on Earth, the starting point on which any battle over guiding moral principles takes place. IPCC reports and many other studies flood the polarized media with harsher and harsher estimations about the future of the climate. We have until 2030 to turn things around. We are past climate change. We are in climate crisis.

So, how can we tame the impetus of economic growth that causes this inertia of mass waste? How can we break the mindset at the core of neoliberal capitalism, that markets will correct the relation of humans with nature? And how can we bring the left, (under whatever label now operates) down to Earth, so people can leapfrog over ideologies and bad memories of communiststyle regimes?

We must talk about new economic rights, in the spirit of Roosevelt, while carefully incorporating talking points from the right and the left. We can talk about market economy, capitaldriven enterprise, Green New Deal, and socializing wealth. The climate crisis demands this new expanded and inclusive narrative. We can gently force the hand of the right and the left to think in a cooperative fashion if we move the stakes to the lowest possible common denominator. Which is, clearly: keeping homo sapiens alive on Earth, and raising the standard of living for all, not just the few. 
Then, we need to deal with politics. Democracies have created these convoluted systems of balance of power, that for good reasons are in deadlock when it comes to breaking with the orthodoxy. Simple, effective, data-driven mechanisms that have the propensity to bring about more economic justice, while pleading the case of the entire political spectrum, have more chances of earning political support and inspire the electorate.

\section{How to Create the Social Branch?}

If we are to borrow a term from philosopher David Chalmers, this is the hard problem. The point of emergence where the economy has a qualia-like moment: it aggregates instances of subjective, conscious experience and attempts to formulate from within a new transformative meta-identity, one that acknowledges itself from outside. Imagine the aerial photographs of Johnny Miller (TEDex Talks, 2017). Seen from the sky, slums are separated by affluent neighborhoods with distinct, hard barriers. Inequality is stark, brutal, visceral. The self-conscious economy ought to think I know what I can become.

The social branch might as well begin with a proclamation by the national government, in the name of its people, after its charter has been vetted through a referendum. The National Account of Wealth will be set up to operate deposits and disbursements immediately. The revenue agencies will transfer their jurisdiction of collecting the agreed upon portion of income taxation to the NAW. Capital taxation, in all its complexity, will also begin partial transfers into the NAW. VAT collection will also be transferred to the NAW by the same ratios agreed in the charter. In its first payment cycle, the social branch should be able to handle monthly equal payments to all citizens to start off the new mechanism at a level of an UBI deemed feasible by many writers and researchers: \$1000 in the US (Yang, 2018), \$1415 in Canada (Forget, 2018), 2555 francs in Switzerland, $192 £$ in the UK (Standing, 2017).

At the same time ECOSOC can establish its own social branch with an international account of wealth (IAW) that will handle similar disbursements to all its members with the caveat that the IAW will have a different charter and different algorithms that will focus more on capital capture, and consumption taxation (VAT) than income taxation ${ }^{7}$. Wealth taxation will have a two-tier

\footnotetext{
${ }^{7}$ Kuypers, Figari, Verbist (2018) showed that if wealth is considered together with income in ranking redistribution, European countries are less redistributive than if considered by the income alone. To which we add that if wealth is progressively socialized through social shares, a much equitable redistribution can be attained.
} 
dynamic distribution: an inverse proportion will be transferred into the NAW and a direct proportion into the IAW, by an aggregated formula that would need to consider at least national GINI coefficients, and other inequality metrics. The scope of the fine balance between the NAW and the IAW is to address both national inequalities and inequalities between countries.

Next come the social shares. Foreseeably, the capital owning lobby will push back the hardest here. The main challenge is to navigate the moral narrative of what the social shares actually represent. They are, not more not less, not communist-style nationalization by the state, but a socialization of wealth that separates executive decision-making from capital creation. All citizens will become owners of the fruits of capital through the mediation of the social branch, but not all citizens will become corporation executives.

All corporations, whether publicly owned or private, will issue mandatory social shares according to the regulations of the social branch charter. The social shares will be instituted in a distinct share class and will have universal rights. The structure and attributes of the social shares are in themselves a grand subject that deserves separate attention. For the purpose of this paper, the social shares must at a minimum preserve these rights: (1) The right of capital owners to determine the course of the enterprise and dispose of investment capital for the purpose of sustainable growth. (2) The right to generate and appropriate profit. (3) The right to establish various forms of property. And the following obligations: (1) Maintain an acceptable ratio of executive-to-worker income. (2) Pay mandatory dividends to the NAW and IAW according to the charter. (3) Make regular disbursements to citizens irrespective of political cycles, from capital that must be allocated from net profits.

Social shares can have a punitive function. In this sense, the social branch will be a disposal of fiscal policy albeit by prescriptive charter instead of government or legislative initiatives. In this sense, the social branch is not the government, it is a citizens-sanctioned administrator. Punitive functions may include: (1) Aberration of pay disparities between executives and workers can be captured by forcing the company to issue progressive number of social shares for each additional increment in executive pay, whether it's salary or pay in stock or other assets. (2) Tax evasion, whether legal or illegal, whether aided by fiscal paradises or financial engineering can be converted into social shares. This requires collaboration with the traditional branches of government to close tax loopholes. Capital flight will become much harder under the new mechanism, since all nations will eventually implement a social branch, being highly incentivized to do so, since the IAW will 
serve as unconditional economic aid especially for developing countries. (3) Corporations will not have much incentives to run away from obligations to the social branch, since the charter can mandate that any indirect presence of said corporation (e.g. convoluted ownership structure, plethora of brands and names etc.) in a national territory makes the corporation subject to the social branch charter. Moreover, their economic activity will be captured by VAT, that will stamp the presence of the capital behind the respective goods and services. (4) Economic activity that damages the environment must be punished. If the fossil fuel industry was forced to issue social shares commensurate to the subsidies they received (which must be terminated immediately) their destructive activity will be curtailed, however they will retain capital which can be used for innovation into renewable energy. The new mechanism is designed to modify behavior and must be presented and perceived as such. Capital is not stolen from the capitalist; it remains with the capital owner.

Social shares will also need to maintain the following attributes, later to be fine-tuned: (1) They cannot be bought or sold. Can only be created by capital-driven corporations and be registered with the social branch. They can be dissolved by the social branch at the request of the corporation in harmony with bankruptcy provisions. (2) Their number must maintain a stable proportion with the rest of shares issued by the corporation. (3) Will be subject to the social branch charter and its prescribed formulas that can be revised by the social branch staff and approved by popular consultation. The $\mathrm{UN}$-administered social branch will have a similar process of adjustment with approval through consultation between nations.

The institutions and instruments thusly created can be used immediately as means to combat overproduction crises or surgically soften the temporary regional disequilibria that can affect global macrostability. Under the guidance of institutions whose mandate is to tackle stability (IMF) and global development (World Bank), funding can increase through intergovernmental issue of fiat currency. ${ }^{8}$ This translates into temporary increasing the UBI in affected regions. In this fashion,

\footnotetext{
${ }^{8}$ Inflation concerns? Somewhat justified but offset by the collection of VAT and simultaneous increases in disbursements to maintain the purchasing power. The algorithm should and must include inflation rates. At the same time, in the background, the presence of crypto currencies also lingers. While at present they are not a major concern for public policy, the cryptos can indeed be leveraged to increase the basket of currencies at the disposal of the new mechanism. Disbursements can include national currency and borderless digital currencies. It may seem a paradox that the social branch leads to the loosening of the status quo, but that is precisely the vision at its core: to relax state power and to empower the citizens much more through the socialization of wealth. Also, the upside of block chain
} 
global economy will be subsidized and stimulated as needed in a transparent and competitive way without affecting deals made from negotiations made within the World Trade Organization. The creative character of crises is salvaged, if such "creative destruction" actually existed (Schumpeter, 1975: 82-85).

\section{Conclusion}

The idea of wealth and income redistribution has wide popular support, when the right questions are asked. Standing like a dormant volcano that has accumulated material under pressure and only needs for the crust to break, the voices of the people only wait for the proper channel and narrative to be heard. In a series or surveys, scientists Michael Norton and Dan Ariely (2011) have showed that the US population, regardless of political orientation, held an ideal of wealth and income inequality at a much lower levels than the reality, while at the same time their estimate of the levels of these inequalities lay somewhat between reality and ideal. Respondents across gender, education levels, political orientation, estimated that the top $20 \%$ richest citizens owed between $50 \%-60 \%$ and stated the ideal ought to be between $30 \%-40 \%$, while in reality the top $20 \%$ owed $85 \%$ of the private wealth. Similarly, when it came to CEO-to-worker income ratio, respondents from 40 countries estimated a ratio of 6-41:1, an ideal ratio of 4-6:1, while the reality is 40-351:1 (the high outlier is the United States). People across the globe do not say they want perfect equality, but they do wish inequalities were much lower.

On data like this, we can build a strong consensus for designing a new mechanism for economic justice. Realistic, non-ideologic, pragmatic proposals such as the one presented in this paper are long due.

UBI is not an instrument that would solve the problem of inequality, but it is good enough to fix a good chunk of the problems caused by inequality. If the amount of UBI ensures decent living, UBI would make inequality less relevant because the blackmail power over workers would

\footnotetext{
technologies must be taken into consideration, since the algorithms behind the social branch will use, heavily, data systems based on socially-focused artificial intelligence, unlike A.I. that is deployed to harvest personal data and enhance surveillance capitalism driven by advertising, manufacturing consent, behavior modification, electoral fraud, all which essentially undermine democracy at its roots. This is a huge topic which may be expanded in later papers. For more see: The Age of Surveillance Capitalism: The Fight for a Human Future at the New Frontier of Power (2018) by Shoshana Zuboff.
} 
disappear. This is the power given by inequality. Workers would not live with the threat of being discarded at the mercy of the market. Moreover, when we disconnect the UBI redistribution mechanism from the short-term political games, we get the guarantee of a status quo that offsets the damaging effects of inequality. Politics and policy tend to deliver solutions with a deep sense of subjective arbitrariness to which voters rarely subscribe wholeheartedly.

We could say that the leftovers of feudalism would be largely exorcized from capitalism. Remaining inequality would be more an inequality of consumption, making it more tolerable and widely more popular. We would be left also with a diversity of strategies and development processes (where to invest first, how to manage access to natural resources etc.) that can be easier to handle than letting politics alone to deal with these questions. The resulting system may become one quite familiar and much closer to human nature, notwithstanding radical changes in work ethic and incentives.

The sweetest part of the new deal is that we would satisfy the right-leaning enthusiasts because they will enjoy more peace of mind and predictability that no authoritarian regime could match. We would also give satisfaction to the left-leaning solidaritarians because they will see many of their visions come to life without the power that some leaders dream about. For all other spectra of visions, from global policy to education and health, we can still enjoy our traditional electoral games.

UBI won't solve the problems caused by automation or economic crises but it will make the transition smoother and will help with softening the adverse effects.

We propose nothing less than a nation-wide and global socialization of wealth. Immediately this flies right in the face of venture capitalists and the like, who continue to ride the wave of neoliberalism with impunity. When trillions of dollars are stashed in fiscal paradises and fake foundations, when democracy is up for sale, when the entire narrative of fair markets has been hijacked by the self-anointed enlightened elites, when masses rise in protest on the verge of climate catastrophe, we believe humanity deserves a new mechanism for economic justice.

\section{References}

1. ACEMOĞLU, Daron and ROBINSON, James A. (2012) Why Nations Fail: The Origins of Power, Prosperity, and Poverty. Crown Business.

2. ATKINSON, Anthony B. (2015) Inequality: What Can Be Done? Harvard University Press. 
3. BREGMAN, Rutger (2016) Utopia for Realists: The Case for a Universal Basic Income, Open Borders, and a 15-hour Workweek. Little, Brown and Company.

4. BUTARU, Lucian T. (2015) "Beyond or Besides Neoliberalism? The Political Economy of Universal Basic Income”. Studia Universitatis Babeș-Bolyai. Studia Europaea, LX, 1.

5. BUTARU, Lucian T. (2017) "Towards a Universal Basic Income. An Evolutionary Approach”. Studia Universitatis Babeș-Bolyai. Studia Europaea, LXII, 3, 2017.

6. COLLIER, Paul (2018) The Future of Capitalism. Facing the New Anxieties. Harper.

7. CUNLIFFE, John and ERREYGERS, Guido (eds.) (2004). The Origins of Universal Grants: An Anthology of Historical Writings on Basic Capital and Basic Income, Palgrave Macmillan.

8. FORGET, Evelyn L. (2018) Basic Income for Canadians: The Key to a Healthier, Happier, More Secure Life for All. Lorimer.

9. FRANKFURT, Harry (2015) On Inequality. Princeton University Press.

10. FREY, Benedikt and OSBORNE, Michael A. (2017) Technological Forecasting and Social Change. vol. 114, North-Holland.

11. GRAEBER, David (2018) Bullshit Jobs: A Theory. Simon \& Schuster.

12. HÄGGLUND, Martin (2019) This Life: Secular Faith and Spiritual Freedom. Pantheon.

13. HAHNEL, Robin and WRIGHT, Erik Olin (2016) Alternatives to Capitalism. Proposals for a Democratic Economy. Verso.

14. KUYPERS, Sarah; FIGARI, Francesco and VERBIST, Gerlinde (2018) "Redistribution in a joint income-wealth perspective: a cross-country comparison". Euromod Working Paper Series. February 2018.

15. LUSTING, Nora (ed.) (2018) Commitment to Equity Handbook. Estimating the Impact of Fiscal Policy on Inequality and Poverty. Brookings Institution Press and CEQ Institute, Tulane University. http://commitmentoequity.org/publications-ceq-handbook.

16. NORTON, Michael and ARIELY, Dan (2011) "Building a Better America One Wealth Quintile at a Time”. Perspectives on Psychological Science, 6:9.

17. OBERMAYER, Bastian and OBERMAIER, Frederik (2016) The Panama Papers: Breaking the Story of How the Rich and Powerful Hide Their Money. Oneworld Publications.

18. PIKETTY, Thomas (2004) L'économie des inégalités. La Découverte.

19. PIKETTY, Thomas (2013) Le Capital au XXIe siècle. Éditions du Seuil. 
20. REICH, Robert (2015) Saving Capitalism: For the Many, Not the Few. Vintage.

21. RUSHKOFF, Douglas (2019) Team Human, WW Norton.

22. SCHUMPETER, Joseph A. (1975) Capitalism, Socialism and Democracy. New York: Harper [orig. pub. 1942].

23. SMITH-CARRIER, Tracy and GREEN, Steven (2017) “Another Low Road to Basic Income? Mapping a Pragmatic Model for Adopting a Basic Income in Canada”. Basic Income Studies, January 2017.

24. STANDING, Guy (2017) The Corruption of Capitalism: Why Rentiers Thrive and Work Does Not Pay. Biteback Publishing.

25. TEDex Talks (2017) This is what inequality looks like $\mid$ Johnny Miller $\mid$ TEDxJohannesburg”. Youtube. https://www.youtube.com/watch?v=IpfMMKT_4jw.

26. VERY, Joseph (2012) The Price of Inequality: How Today's Divided Society Endangers Our Future. W.W. Norton \& Company.

27. STIGLITZ, Joseph (2019) People, Power, and Profits: Progressive Capitalism for an Age of Discontent. W. W. Norton \& Company.

28. VAN PARIJS, Philippe (1998) Real Freedom for All. What (If Anything) Can Justify Capitalism?, New York: Oxford University Press.

29. VIVEKINAN, Ashok; KUZIEMKO, Ilyana and WASHINGTON, Ebonya (2015) "Support for Redistribution in an Age of Rising Inequality: New stylized facts and some tentative explanations", BPEA Conference Draft, March 19-20, 2015.

30. WEYL, Glen and POSNER, Eric (2018) Radical Markets: Uprooting Capitalism and Democracy for a Just Society. Princeton University Press.

31. WIDERQUIST, Karl (2013) “Is Basic Income Still Worth Talking About?”. The Economics of Inequality, Poverty, and Discrimination in the 21st Century, Volume II, Robert S Rycroft (ed.) Santa Barbara, CA: ABC-CLIO, pp. 568-584.

32. WORLD BANK (2019) “GDP (current US\$). World Bank national accounts data, and OECD National Accounts data files". https://data.worldbank.org/indicator/ny.gdp.mktp.cd.

33. UNU-Wider (2018) "World Income Inequality Database”. https://www.wider.unu.edu/project/wiid-world-income-inequality-database.

34. WID (2018) “World Inequality Report”. https://wir2018.wid.world. 
35. YANG, Andrew (2018) The War on Normal People: The Truth About America's Disappearing Jobs and Why Universal Basic Income Is Our Future. Hachette Books.

36. YOUNG, Claire (2017) "How reforms to tax policy could help close the wealth gap in Canada”. The Monitor, Jan-Feb 2017.

37. ZUBOFF, Shoshana (2018) The Age of Surveillance Capitalism: The Fight for a Human Future at the New Frontier of Power. PublicAffairs. 